\title{
ASPEK-ASPEK PERTIMBANGAN DALAM BERKARIR SEBAGAI AKUNTAN PUBLIK
}

\author{
Amalia Suryani \\ Fakultas Ekonomi dan Bisnis Universitas Dian Nuswantoro \\ Zaky Machmuddah \\ Fakultas Ekonomi dan Bisnis Universitas Dian Nuswantoro \\ email: zaky.machmuddah@dsn.dinus.ac.id
}

\begin{abstract}
This study aims to prove empirically the effect of financial rewards, labor market considerations, professional training, work environment, professional recognition, and social value on career interests as public accountants. The population of this study isungraduate accounting students of 2014 amounts of 743 students and is obtained samples of 260 students. The obtained are data categorized as primary data getting by distributing questionnaires and secondary data. The test results prove that the professional training, work environment, professional recognition, and social value have significant effects on career interests as public accountants, unlike the variables of financial presentation and labor market considerations, the test results prove that those variables have no effect on career interest as public accountants.
\end{abstract}

Keywords: career interest, aspect consideration, profession of public accountant.

\begin{abstract}
ABSTRAK
Penelitian ini bertujuan untuk membuktikan secara empiris pengaruh penghargaan finansial, pertimbangan pasar kerja, pelatihan profesional, lingkungan kerja, pengakuan profesional, dan nilai-nilai sosial terhadap minat berkarir sebagai akuntan publik. Populasi yang digunakan adalah mahasiswa program studi S1 Akuntansi angkatan 2014 sejumlah 743 mahasiswa dan didapat ukuran sampel sejumlah 260 responden. Data yang telah didapat dikategorikan sebagai data primer yang dikantongi dengan cara membagikan kuesioner dan data sekunder. Hasil pengujian membuktikan jika variabel pelatihan profesional, lingkungan kerja, pengakuan profesional, dan nilai-nilai sosial berpengaruh signifikan terhadap minat berkarir sebagai akuntan publik, berbeda dengan variabel penghargaan finansial dan pertimbangan pasar kerja, hasil pengujian membuktikan tidak berpengaruh terhadap minat berkarir sebagai akuntan publik.
\end{abstract}

Kata kunci : minat karir, aspek pertimbangan, profesi akuntan publik.

\section{PENDAHULUAN}

Kebutuhan dunia kerja akan akuntan profesional sangat tinggi. Berdasarkan data dari (www.sindonews.com) pada tahun 2014 sekitar 226.000 lembaga di Indonesia membutuhkan jasa akuntan profesional. Sedangkan, menurut data Pusat Pembinaan Akuntan dan Jasa Penilai (PPAJP) Kementerian Keuangan jumlah pekerja yang ada tidak lebih sebanyak 16.000 orang, dengan demikian Indonesia dapat dikatakan mengalami krisis tenaga akuntan profesional, khususnya akuntan publik.

Jumlah akuntan publik di Indonesia, pada tahun 2013 menempati urutan ke-6 dari 11 negara yang menjadi anggota ASEAN setelah Singapura 15.120, Filipina 15.020, Thailand 6.070, Malaysia 2.460, Vietnam 1500, dan Indonesia 998 (www.iapi.or.id). Dilihat dari data 
pusat pembinaan profesi keuangan sekretariat jenderal kementrian keuangan pada tahun 2014 akuntan publik berjumlah 1.053 orang, dari jumlah penduduk sebanyak 234 juta jiwa dengan presentase perbandingan $0,0004 \%$. Berbeda dengan Singapura yang jumlah penduduknya hanya sekitar 5 juta jiwa, mempunyai akuntan publik mencapai 15.120 dengan presentase perbandingan $0,3024 \%$.

Porsi akuntan muda dan tua di Indonesia tidak berimbang, dari 1053 jiwa usia kurang dari 30 tahun berjumlah 10 orang dengan presentase $0,94 \%$, usia 31 sampai dengan 39 tahun berjumlah 132 orang dengan presentase $12,54 \%$, usia 40 - 49 tahun sebanyak $28,97 \%$, usia 50 - 59 tahun berjumlah 273 orang dengan presentase $25,93 \%$, dan usia diatas 59 tahun berjumlah 333 dengan presentase 31,62\%, yang artinya Indonesia dalam beberapa tahun kedepan akan mengalami krisis jumlah akuntan publik, karena porsi akuntan yang memasuki masa pensiun mencapai 57,55\%. Sedangkan jumlah register akuntan pada tahun 2015 mencapai 52.000 (www.iaiglobal.or.id).

Jumlah tersebut setiap tahun terus meningkat, dengan besarnya lulusan sarjana akuntansi di Indonesia. Namun, menurut Sukrisno Agoes selaku Dewan Kehormatan IAPI mengungkapkan bahwa fresh graduate yang tertarik untuk menekuni profesi akuntan publik sangat sedikit. Hal itu mungkin dikarenakan risiko akuntan publik yang ditanggung lebih besar, yaitu dalam mengaudit laporan keuangan perusahaan yang diaudit, akuntan publik harus mampu menjaga independensi. Sedangkan penghasilan yang diperoleh sebagai jasa akuntan publik, tidak sebanding dengan beban risiko yang harus ditanggung (www.kompas.com). Minimnya minat untuk menekuni profesi akuntan publik, tingginya kebutuhan akan akuntan profesional, dan terbukanya lapangan pekerjaan dapat memberikan kesempatan besar bagi mahasiswa akuntansi dalam menetapkan pekerjaan yang akan ditekuni yaitu sebagai akuntan publik.

Akuntan publik adalah seorang yang sudah mendapat izin dari menteri keuangan guna memberikan pelayanan publik, seperti halnya diatur menurut undang-undang nomor 5 tahun 2011 dan peraturan yang ditetapkan menteri keuangan nomor 443/KMK.01.2011 mengenai penetapan institut akuntan publik indonesia sebagai asosiasi profesi akuntan publik Indonesia (IAPI). IAPI, merupakan asosiasi profesi yang legal dan setiap akuntan publik wajib menjadi anggota IAPI. Profesi akuntan publik mempunyai peran penting pada perekonomian, yaitu berperan dalam menaikkan kualitas dan kredibilitas governance.

Kebutuhan akuntan publik yang tinggi namun jumlahnya kurang memadai, sehingga menyebabkan terbukanya lapangan pekerjaan dapat menjadi daya tarik utama untuk berprofesi menjadi akuntan publik. Pilihan menekuni profesi akuntan publik, dapat timbul dengan adanya aspek-aspek yang diduga menjadi pendorong, yaitu penghargaan finansial, pertimbangan pasar kerja, pelatihan profesional, lingkungan kerja, pengakuan profesional, dan nilai-nilai sosial.

Berdasarkan penelitian yang sudah dilaksanakan oleh peneliti-peneliti sebelumnya, namun demikian hasil penelitian memperlihatkan adanya perbedaan hasil yang diperoleh tidak konsisten. Hal ini dimungkinkan terjadi karena terdapat perbedaan responden, tempat, dan tahun dilakukannya penelitian.

Penelitian yang dilakukan Yanti (2014), Saputra (2015) dan Rindani (2015) menyebutkan bahwa penghargaan finansial memiliki pengaruh signifikan terhadap pemilihan karir mahasiswa akuntansi untuk berkarir sebagai akuntan publik. Berbeda dengan hasil penelitian yang dilaksanakan oleh Sari (2013) menunjukkan bahwa penghargaan finansial tidak memiliki pengaruh terhadap minat menjadi akuntan publik.

Pada saat pertimbangan pasar kerja dijadikan variabel independen, hasil penelitian Sari (2013) selaras dengan hasil penelitian yang dilaksanakan oleh Yanti (2014) dan Rindani (2015), yang menyatakan bahwa pertimbangan pasar kerja berpengaruh secara signifikan terhadap minat menjadi akuntan publik. Sedangkan Wahyuni (2016) dan Saputra (2015) 
dalam penelitiannya berpendapat bahwa pertimbangan pasar kerja tidak mempunyai pengaruh terhadap minat mahasiswa akuntansi untuk berkarir menjadi akuntan publik.

Pelatihan profesional merupakan salah satu faktor yang menjadi pertimbangan dalam pemilihan karir sebagai akuntan publik. Hasil temuan Rindani (2015) dan Saputra (2015) membuktikan bahwa pelatihan profesional mempunyai pengaruh terhadap minat mahasiswa akuntansi untuk berkarir menjadi akuntan publik. Hal tersebut tidak sejalan dengan hasil penelitian Sari (2013) yang mengungkapkan pelatihan profesional tidak memiliki pengaruh terhadap minat menjadi akuntan publik.

Hasil penelitian Wahyuni, dkk. (2016) yang didukung penelitian dari Yanti (2014), menunjukkan bahwa lingkungan kerja berpengaruh secara positif terhadap minat mahasiswa akuntansi untuk menekuni karir sebagai akuntan publik. Berbeda dengan Sari (2013) dan Saputra (2015), yang mengemukakan bahwa lingkungan kerja tidak memiliki pengaruh terhadap minat menjadi akuntan publik

Ketika pengakuan profesional dijadikan faktor yang berpengaruh terhadap pemilihan karir sebagai akuntan publik, Sari (2013) dalam penelitiannya yang juga didukung dengan penelitian Yanti (2014) serta Wahyuni (2016) mengemukakan pengakuan profesional berpengaruh terhadap minat menjadi akuntan publik. Berbeda dengan yang diungkapkan Rindani (2015) pengakuan profesional atau penghargaan profesional tidak mempunyai pengaruh terhadap minat mahasiswa untuk menekuni karir sebagai akuntan publik.

Begitu pula dengan nilai-nilai sosial ketika dijadikan variabel yang mempengaruhi pemilihan karir sebagai akuntan publik. Hasil penelitian Saputra (2015) dan Wahyuni, dkk. (2016) menyatakan bahwa nilai-nilai sosial berpengaruh terhadap minat menjadi akuntan publik. Namun hal berbeda ditunjukkan oleh hasil penelitian Sari (2013), Yanti (2014), dan Rindani (2015) yakni nilai sosial kerja tidak memiliki pengaruh terhadap minat mahasiswa untuk berkarir sebagai akuntan publik.

Penelitian ini merupakan replikasi dari peneliti sebelumnya yaitu Sari (2013). Persamaan penelitian Sari (2013) dengan peneliti ialah memakai variabel yang sama. Adapun perbedaan penelitian ini dengan penelitian Sari (2013) ialah populasi dan sampel, tahun, dan tempat dilakukannya penelitian.

Mahasiswa S1 akuntansi Universitas Muhammadiyah Medan dengan kriteria sampel, mahasiswa yang sedang mengajukan proposal penelitian skripsi dan mahasiswa yang sudah mempunyai Indeks Prestasi Kumulatif (IPK) sebesar 3,0 dijadikan populasi dan sampel penelitian oleh Sari (2013), dengan tahun penelitian 2013. Sedangkan, pada penelitian ini populasi dan sampel yang dipakai adalah mahasiswa S1 akuntansi Universitas Dian Nuswantoro, Universitas Katolik Soegijapranata, dan Universitas Stikubank angkatan 2014 dengan tahun penelitian 2017. Alasan utama peneliti dalam memilih lokasi pengambilan sampel pada tiga perguruan tinggi tersebut yaitu program studi dari ketiga perguruan tinggi tersebut akreditasi A (BAN-PT). Sedangkan alasan pendukung dengan memilih tempat sampel yang berbeda adalah untuk memperluas wilayah pengambilan sampel.

Berdasarkan latar belakang yang dipaparkan diatas, persoalan yang akan diteliti dalam penelitian ini adalah (1) apakah penghargaan finansial mempunyai pengaruh terhadap minat berkarir sebagai akuntan publik?, (2) apakah pertimbangan pasar kerja mempunyai pengaruh terhadap minat berkarir sebagai akuntan publik?, (3) apakah pelatihan kerja profesional mempunyai pengaruh terhadap minat berkarir sebagai akuntan publik?, (4) apakah lingkungan kerja mempunyai pengaruh terhadap minat berkarir sebagai akuntan publik?, (5) apakah pengakuan profesional mempunyai pengaruh terhadap minat berkarir sebagai akuntan publik?, dan (6) apakah nilai-nilai sosial mempunyai pengaruh terhadap minat berkarir sebagai akuntan publik?. Sehingga tujuan utama dari penelitian ini adalah untuk menguji aspek-aspek yang mempengaruhi minat berkaris sebagai akuntan publik. 


\section{INJAUAN LITERATUR DAN PERUMUSAN HIPOTESIS}

\section{Teori Persepsi}

Robbins (2003), mendeskripsikan persepsi dalam hubungannya dengan lingkungan, yaitu sebagai tahap dimana orang-orang mengkoordinasikan dan mengartikan kesan indera mereka, supaya memberi arti pada lingkungan sekitar. Sedangkan Walgito (2004) mengemukakan persepsi ialah proses yang terjadi pada diri seseorang, mulai dari diperolehnya rangsang, sampai rangsang itu disadari dan dipahami oleh seseorang, hingga seseorang mampu mengenali dirinya sendiri dan keadaan disekelilingnya. Jadi, persepsi adalah proses perlakuan individu yaitu menanggapi, mengartikan, menggambarkan, terhadap apa yang terlihat, terdengar atau dirasakan dalam bentuk tindakan, opini, dan perbuatan.

\section{Teori Motivasi Kerja}

\section{Teori Hierarki Kebutuhan}

Menurut Maslow (1954), teori hierarki kebutuhan berpendapat bahwa kebutuhankebutuhan tingkat dasar (bawah) harus tercukupi lebih dulu sebelum mengejar kebutuhankebutuhan pada tingkat lebih tinggi. kebutuhan-kebutuhan tersebut yaitu kebutuhan fisiologis (physiologikal needs), kebutuhan akan keamanan (safety/security needs), kebutuhan akan kasih sayang dan rasa memiliki (social needs), Kebutuhan akan harga diri (esteem needs), Kebutuhan aktualisasi diri (self actualization needs).

\section{Teori Dua Faktor}

Menurut Herzberg (2005) ada 2 jenis faktor yang mendorong seseorang untuk berusaha mencapai kepuasan dan menjauhkan diri dari ketidakpuasan. Faktor intrinsik meliputi orientasi terhadap uang, pengakuan, persaingan, dan perintah orang lain, dan yang terakhir mencakup tantangan, kenikmatan, pengayaan pribadi, minat, dan penentuan nasib sendiri. Faktor ektrinsik meliputi pengawasan, kebijakan dan administrasi perusahaan, hubungan interpersonal, gaji, kondisi kerja, status, dan keamanan.

\section{ERG Theory (Existence, Relatedness, Growth)}

Aldefter (1972) mengembangkan hierarki kebutuhan Maslow dengan mengkategorikan hierarki kedalam teori ERG-nya yang terdiri dari: eksistensi, keterkaitan dan pertumbuhan. Eksistensi mencakup yang menurut Maslow dianggap sebagai kebutuhan fisiologis dan keamanan. Keterkaitan mencakup yang menurut Maslow dianggap sebagai kebutuhan akan kasih sayang dan rasa memiliki dan kebutuhan akan harga diri pertumbuhan ini mencakup yang menurut Maslow dianggap sebagai kebutuhan aktualiasi diri.

\section{Teori X dan Teori Y oleh Douglas McGregor}

McGregor (2000) merumuskan asumsi-asumsi dan perilaku manusia dalam organisasi terdiri dari: Teori $\mathrm{X}$, mengungkapkan pada umumnya, pegawai malas dan enggan untuk bekerja. Adanya anggapan seperti itu, untuk menjalankan perusahaan manajemen condong untuk memakai gaya otoriter. Teori $\mathrm{Y}$, mengungkapkan pada umumnya pegawai dalam bekerja mencintai pekerjaannya, bekerja penuh dengan tanggung jawab, kreatif, termotivasi, bangga terhadap hasil kerja yang dicapai, dan menyukai tantangan baru. Adanya pendapat seperti itu, untuk menjalankan perusahaan manajemen condong untuk menerapkan gaya partisipatif.

\section{Perumusan Hipotesis}

Salah satu faktor yang membuat orang mau bekerja yaitu keinginan untuk hidup, merupakan keinginan terpenting semua manusia, untuk dapat menyambung hidupnya, 
seseorang butuh makan dan minum, untuk memenuhi kebutuhannya seseorang harus bekerja, dengan bekerja seseorang akan mendapatkan timbal balik berupa gaji. Gaji atau kompensasi menurut Marwansyah (2010) merupakan pembayaran yang diberikan oleh organisasi atau perusahaan kepada pegawai sebagai suatu balas jasa yang diberikannya kepada organisasi atau perusahaan.

Salah satu kebutuhan fisiologis dalam teori hierarki kebutuhan Maslow (1954) adalah kebutuhan akan makanan dan minuman, untuk dapat membeli makan dan minum manusia membutuhkan uang, dan uang didapat setelah seseorang tersebut bekerja. Sejalan dengan hal itu, Aldefter (1972) mengembangkan hierarki kebutuhan Maslow dengan mengkategorikan hierarki kedalam teori ERG nya. Salah satu teori ERG adalah eksistensi, kelompok ini berkepentingan dengan penyediaan materi dasar kebutuhan manusia. Ini mencakup barangbarang yang menurut Maslow dianggap sebagai kebutuhan fisiologis dan keamanan.

Hasil penelitian yang dilakukan Yanti (2014), Saputra (2015) dan Rindani (2015) mengemukakan bahwa penghargaan finansial berpengaruh terhadap minat mahasiswa akuntansi untuk berkarir sebagai akuntan publik. Dari penelitian terdahulu yang dipaparkan diatas, maka hipotesis pertama penelitian ini sebagai berikut :

\section{H1: Penghargaan finansial berpengaruh terhadap minat berkarir sebagai akuntan}

Salah satu faktor utama yang dipertimbangkan seseorang dalam memilih jenis karir atau profesi adalah pertimbangan pasar kerja. Pertimbangan pasar kerja terdiri dari keamanan kerja, lapangan kerja yang ada dan lowongan kerja yang mudah diakses. Keamanan kerja dalam hal ini berkaitan dengan tidak mudah di PHK, karena seperti yang kita ketahui pada saat ini persaingan dalam dunia kerja sangat ketat sehingga akan sulit dalam mendapatkan pekerjaan. Sedangkan tersedianya lapangan kerja dan kemudahan mengakses lowongan kerja berkaitan dengan informasi seberapa banyak lowongan kerja yang dapat diakses.

Kebutuhan akan keamanan yang meliputi kebutuhan akan proteksi, jaminan keamanan, stabilitas, struktur, hukum, keteraturan, dan bebas dari rasa cemas dan takut merupakan bagian dari teori Maslow (1954). Sejalan dengan hal itu, salah satu teori ERG Aldefter (1972) adalah eksistensi, kelompok ini berkepentingan dengan penyediaan materi dasar kebutuhan manusia, mencakup barang-barang yang menurut Maslow dianggap sebagai kebutuhan fisiologis dan keamanan.

Temuan penelitian Sari (2013), Yanti (2014) dan Rindani (2015) menyatakan bahwa pertimbangan pasar kerja berpengaruh terhadap minat mahasiswa akuntansi untuk berkarir sebagai akuntan publik. Berdasarkan argumentasi dan temuan penelitian terdahulu yang dipaparkan diatas, maka hipotesis kedua penelitian ini sebagai berikut:

\section{H2: Pertimbangan pasar kerja berpengaruh terhadap minat berkarir sebagai akuntan publik.}

Setelah calon pekerja lolos dari proses seleksi dan diterima, kerapkali kemampuan, potensi dan keahlian yang dipunyai belum sesuai dengan yang diharapkan, oleh karena itu perlu dilaksanakan pelatihan guna mencapai produktifitas. Latihan dan pengembangan dapat diartikankan sebagai suatu usaha terencana dari lembaga guna meningkatkan keterampilan, pengetahuan, dan kemampuan karyawan (Hariandja, 2002). Alasan mengapa pelatihan kerja harus dilakukan (Hariandja, 2002) yaitu pekerja yang baru diterima kerapkali tidak menguasai cara mengerjakan tugas yang diberikan, adanya perubahan di lingkungan kerja dan tenaga kerja, agar daya saing perusahaan meningkat dan membenahi produktivitas, dan menyinkronkan dengan ketentuan yang ada.

Lingkungan kerja selaras dengan kebutuhan akan harga diri. Kebutuhan akan harga diri yang dikemukakan oleh Maslow (1954) dibagi dua, salah satunya adalah menghargai diri 
sendiri yang meliputi kebutuhan akan kemandirian, penguasaan, kekuatan, dan kompetensi percaya diri.

Saputra (2015) dan Rindani (2015) membuktikan pelatihan profesional berpengaruh terhadap minat menjadi akuntan publik. Dari hasil penelitian terdahulu yang dipaparkan diatas, maka hipotesis ketiga penelitian ini sebagai berikut:

\section{H3: Pelatihan profesional berpengaruh terhadap minat berkarir sebagai akuntan publik.}

Nitisemito (2002) berpendapat bahwa lingkungan kerja sebagai sesuatu yang ada disekitar para pekerja, dan yang dapat mempengaruhi dirinya dalam memberikan tugas-tugas yang dibebankan. Lingkungan kerja memiliki pengaruh yang besar dalam produktivitas pekerja. Lingkungan kerja akuntan publik lebih banyak menuntut untuk dapat menghadapi berbagai tantangan yang berbeda sehingga menimbulkan tekanan kerja yang mengakibatkan dapat memberikan hasil yang maksimal. Tekanan kerja disini berkaitan dengan adanya tuntutan dari klien dengan memberi batas waktu sehingga mewajibkan seorang akuntan publik lembur untuk menyelesaikan tugasnya dan tentunya akan terjadi persaingan yang ketat setiap pegawai.

Davis dan Noe mengklasifikasikan kompensasi kedalam kompensasi finansial dan kompensasi non finansial (Marwansyah, 2010). Kompensasi non finansial berpendapat bahwa kompensasi non finansial mencakup seseorang menerima berbagai bentuk kepuasan dari pekerjaan itu sendiri, atau yang berupa lingkungan psiologis dan atau lingkungan fisik tempat seseorang bekerja. Kepuasan yang berasal dari pekerjaan dapat berupa tugas-tugas yang menarik, tantangan, dan tanggung jawab. Contoh kepuasan yang berasal dari lingkungan kerja adalah lingkungan kerja yang menyenangkan, atasan yang kompeten, kondisi kerja yang nyaman, dan penyediaan kafetaria.

Faktor intrinsik meliputi orientasi terhadap uang, pengakuan, persaingan, dan perintah orang lain, dan yang terakhir mencakup tantangan, kenikmatan, pengayaan pribadi, minat, dan penentuan nasib sendiri merupakan sebagian dari teori dua faktor Herzberg (2000). Teori X McGregor (2000), mengungkapkan pada umumnya, pegawai malas dan enggan untuk bekerja, sehingga gaya otoriter akan digunakan oleh manajemen perusahaan. Teori Y, mengungkapkan pada umumnya pegawai dalam bekerja mencintai pekerjaannya, bekerja penuh dengan tanggung jawab, kreatif, termotivasi, bangga terhadap hasil kerja yang dicapai, dan menyukai tantangan baru, oleh karena itu gaya partisipatif diterapkan oleh manajemen perusahaan.

Hasil penelitian Wahyuni, dkk. (2016) menunjukkan bahwa lingkungan kerja berpengaruh positif terhadap minat mahasiswa akuntansi untuk berkarir menjadi akuntan publik. Hal ini didukung oleh hasil penelitian yang dilakukan Yanti (2014). Dari hasil penelitian terdahulu yang dipaparkan diatas, maka hipotesis keempat adalah:

\section{H4: Lingkungan kerja berpengaruh terhadap minat berkarir sebagai akuntan publik.}

Pengakuan profesional meliputi hal-hal yang berhubungan dengan pengakuan terhadap prestasi (Sari, 2013). Sebagai contoh pengakuan (terhadap prestasi) yang diperoleh dari manajer, rekan kerja, atau konsumen. Kebutuhan akan penghargaan yang diungkapkan oleh Maslow (1954) terdiri dari: prestise, ketenaran, dominasi, status, kehormatan, diterima, penghargaan dari orang lain, diapresiasi, dan menjadi orang penting. Pengakuan profesional juga berhubungan dengan teori yang dikemukakan oleh Herzberg (2005) dalam teori dua faktor yang memotivasi orang mau bekerja sebagai pencapaian, pekerjaan itu sendiri, pengakuan suatu prestasi, pertumbuhan atau kemajuan yang bersifat instrinsik dan tanggung jawab. 
Sari (2013) dan Yanti (2014) telah membuktikan bahwa pengakuan profesional berpengaruh terhadap minat menjadi akuntan publik. Atas dasar penjelasan yang telah dipaparkan dan hasil penelitian terdahulu, maka hipotesis kelima adalah:

\section{H5: Pengakuan profesional berpengaruh terhadap minat berkarir sebagai akuntan publik.}

Kemampuan seseorang di masyarakat adalah salah satu faktor yang berkaitan dengan nilai-nilai sosial dan sudut pandang orang lain di lingkungannya dapat menunjukkan nilai seseorang (Sari, 2013). Akuntan publik dalam memberikan jasa membutuhkan kepercayaan dari masyarakat yang menjadi kliennya. Masyarakat akan percaya terhadap jasa yang diberikan, apabila standar mutu yang diterapkan tinggi. Kepuasan kerja akuntan publik dapat dilihat dengan membandingkan rekan kerja atau rekan seprofesi lain (sama-sama berprofesi sebagai akuntan). Akuntan publik biasanya ditugaskan ke berbagai tempat dengan perusahaan-perusahaan yang berbeda sehingga dapat menambah pengalaman bagi akuntan itu sendiri selain itu kesempatan untuk berinteraksi dengan ahli lain akan semakin banyak.

Nilai-nilai sosial berkaitan dengan salah satu teori hierarki kebutuhan Maslow (1954) yaitu mengenai kebutuhan akan harga diri. Ada dua macam kebutuhan akan harga diri yaitu menghargai diri sendiri dan memperoleh penghargaan dari orang lain. Menghargai diri sendiri meliputi kebutuhan akan kemandirian, penguasaan, kekuatan dan kompetensi percaya diri dan memperoleh penghargaan dari orang lain kebutuhan akan kedudukan, ketenaran, dominasi, status, kehormatan, diterima, penghargaan dari orang lain, diapresiasi dan menjadi orang penting. Nilai-nilai sosial juga sesuai dengan teori persepsi, adanya persepsi yang timbul dari masyarakat akan suatu pekerjaan, maka akan semakin termotivasi seseorang untuk memilih jenis pekerjaan tententu, yang tentunya akan menciptakan suatu persepsi baik untuk masyarakat ataupun seseorang yang melakukan pekerjaan itu sendiri atas suatu pekerjaan.

Saputra (2015) dan Wahyuni, dkk. (2016) menyatakan nilai-nilai sosial, berpengaruh positif terhadap minat menjadi akuntan publik. Dari hasil penelitian terdahulu yang dipaparkan diatas, maka hipotesis keenam penelitian ini sebagai berikut:

\section{H6 : Nilai-nilai sosial berpengaruh terhadap minat berkarir sebagai akuntan publik.}

\section{METODA PENELITIAN}

\section{Populasi dan Sampel}

Mahasiswa program studi S1 akuntansi angkatan 2014 dijadikan sebagai populasi dalam penelitian ini. Penentuan jumlah sampel menggunakan rumus slovin dengan error 5\% sehingga diperoleh 260 sampel penelitian. Pengambilan sampel dilakukan di Universitas Dian Nuswantoro, Universitas Katolik Soegijapranata, dan Universitas Stikubank Semarang. Proportionate stratified random sebagai metoda yang digunakan dalam menentukan jumlah sampel setiap universitas.

Data primer dan data sekunder merupakan sumber data yang dapat memberikan informasi. Data primer diperoleh melalui membagikan kuesioner kepada responden, sedangkan data sekunder diperoleh dari jurnal, buku, dan dokumen lain yang berkaitan dengan penelitian. Metoda pengumpulan datanya menggunakan teknik convenience sampling. Analisis regresi linier berganda digunakan untuk menganalisis data. 


\section{HASIL DAN PEMBAHASAN}

Jumlah populasi penelitian sebanyak 743 mahasiswa, dengan menggunakan rumus slovin didapat 260 sampel penelitian. Untuk menentukan jumlah sampel dari tiap-tiap universitas digunakan proportionate stratified random. Hasil perhitungan menunjukkan bahwa 77 responden diperoleh dari Universitas Dian Nuswantoro, 79 responden diperoleh dari Universitas Katolik Soegijapranata dan responden yang terbanyak diperoleh dari Universitas Stikubank, yaitu sebanyak 104 responden. Setelah kuesioner disebarkan, didapat hasil bahwa seluruh responden pada penelitian ini berada pada kelompok usia $\geq 20$ tahun.

Hasil identifikasi menunjukkan bahwa responden berjenis kelamin laki-laki berjumlah 80 responden atau sebanyak $30,77 \%$ dan responden berjenis kelamin perempuan berjumlah 180 responden atau sebanyak 69,77\%. Sehingga dapat disimpulkan bahwa responden terbanyak merupakan responden berjenis kelamin perempuan.

Tabel 1 menunjukkan bahwa nilai Cronbach's Alpha instrument untuk semua variabel penelitian nilainya $>0,70$ sehingga dapat dikatakan bahwa instrument dalam penelitian ini adalah reliabel dan layak untuk digunakan.

Tabel 1. Hasil Uji Reliabilitas

\begin{tabular}{|c|l|l|l|l|}
\hline $\begin{array}{c}\text { N } \\
\text { o }\end{array}$ & \multicolumn{1}{|c|}{$\begin{array}{c}\text { Variab } \\
\text { el }\end{array}$} & $\begin{array}{c}\text { Cronbach's } \\
\text { alpha hasil }\end{array}$ & $\begin{array}{c}\text { Cronbach' } \\
\text { S alpha }\end{array}$ & Kriteria \\
\hline 1 & Penghargaan Finansial (X1) & 0,804 & 0,70 & Reliabel \\
\hline 2 & Pertimbangan Pasar Kerja (X2) & 0,770 & 0,70 & Reliabel \\
\hline 3 & Pelatihan Profesional (X3) & 0,757 & 0,70 & Reliabel \\
\hline 4 & Lingkungan Kerja (X4) & 0,718 & 0,70 & Reliabel \\
\hline 5 & Pengakuan Profesional (X5) & 0,769 & 0,70 & Reliabel \\
\hline 6 & Nilai-Nilai Sosial (X6) & 0,758 & 0,70 & Reliabel \\
\hline 7 & $\begin{array}{l}\text { Minat Berkarir Sebagai Akuntan } \\
\text { Publik (Y) }\end{array}$ & 0,747 & 0,70 & Reliabel \\
\hline
\end{tabular}

Tabel 2 menunjukkan hasil uji validitas, terlihat bahwa nilai $r$ hitung lebih besar dari $r$ tabel. Hal ini berarti bahwa semua variabel lolos dalam uji validitas dengan kata lain semua indikator mampu mengkonstruksi variabel-variabel penelitian.

Tabel 2. Hasil Uji Validitas

\begin{tabular}{|c|c|c|c|c|c|c|c|}
\hline No & Indikator & $\begin{array}{l}\mathrm{r} \\
\text { hitung }\end{array}$ & $\mathrm{r}$ tabel & No & Indikator & r hitung & $\mathrm{r}$ tabel \\
\hline 1 & \multirow{4}{*}{$\begin{array}{l}\text { Penghargaa } \\
\text { n Finansial } \\
\text { (X1) }\end{array}$} & 0,674 & 0,1217 & 19 & \multirow{4}{*}{$\begin{array}{l}\text { Pengakuan } \\
\text { Profesional } \\
\text { (X5) }\end{array}$} & 0,596 & 0,1217 \\
\hline 2 & & 0,694 & 0,1217 & 20 & & 0,622 & 0,1217 \\
\hline 3 & & 0,600 & 0,1217 & 21 & & 0,551 & 0,1217 \\
\hline 4 & & 0,512 & 0,1217 & 22 & & 0,515 & 0,1217 \\
\hline 5 & \multirow{5}{*}{$\begin{array}{l}\text { Pertimbang } \\
\text { an Pasar } \\
\text { Kerj } \\
\text { a (X2) }\end{array}$} & 0,672 & 0,1217 & 23 & \multirow{6}{*}{$\begin{array}{l}\text { Nilai- } \\
\text { Nilai } \\
\text { Sosial } \\
\text { (X6) }\end{array}$} & 0,440 & 0,1217 \\
\hline 6 & & 0,643 & 0,1217 & 24 & & 0,589 & 0,1217 \\
\hline 7 & & 0,402 & 0,1217 & 25 & & 0,579 & 0,1217 \\
\hline 8 & & 0,626 & 0,1217 & 26 & & 0,448 & 0,1217 \\
\hline 9 & & 0,378 & 0,1217 & 27 & & 0,529 & 0,1217 \\
\hline 10 & \multirow{4}{*}{$\begin{array}{l}\text { Pelatiha } \\
\mathrm{n} \\
\text { Profesion } \\
\text { al (X3) }\end{array}$} & 0,559 & 0,1217 & 28 & & 0,414 & 0,1217 \\
\hline 11 & & 0.474 & 0,1217 & 29 & \multirow{3}{*}{$\begin{array}{l}\text { Minat } \\
\text { Berkar } \\
\text { ir Sebagai }\end{array}$} & 0,540 & 0,1217 \\
\hline 12 & & 0,667 & 0,1217 & 30 & & 0,436 & 0,1217 \\
\hline 13 & & 0,536 & 0,1217 & 31 & & 0,506 & 0,1217 \\
\hline
\end{tabular}




\begin{tabular}{|c|c|c|c|}
\hline 14 & \multirow{5}{*}{$\begin{array}{l}\text { Lingkung } \\
\text { an Kerja } \\
(\mathrm{X} 4)\end{array}$} & 0,529 & 0,1217 \\
\hline 15 & & 0,615 & 0,1217 \\
\hline 16 & & 0,436 & 0,1217 \\
\hline 17 & & 0,511 & 0,1217 \\
\hline 18 & & 0,304 & 0,1217 \\
\hline
\end{tabular}

\begin{tabular}{|l|l}
\hline 32 & Akuntan \\
\cline { 1 - 1 } 33 & Publik (Y) \\
\cline { 1 - 1 } 34 & \\
\cline { 1 - 1 } 35 & \\
\hline
\end{tabular}

\begin{tabular}{|l|l|}
\hline 0,491 & 0,1217 \\
\hline 0,474 & 0,1217 \\
\hline 0,473 & 0,1217 \\
\hline 0,312 & 0,1217 \\
\hline
\end{tabular}

\section{Penghargaan Finansial dan Minat Berkarir Sebagai Akuntan Publik}

Penelitian ini membuktikan bahwa variabel penghargaan finansial tidak berpengaruh terhadap minat berkarir sebagai akuntan publik (lihat tabel 3). Hasil penelitian ini membuktikan bahwa setiap kenaikan satu satuan penghargaan finansial yang diwakilkan dengan menawarkan gaji awal yang tinggi, memberikan jaminan dimasa depan (dana pensiun), potensi kenaikan gaji yang relatif cepat, dan disediakannya uang transportasi dan uang makan profesi akuntan publik tidak mempengaruhi minat berkarir sebagai akuntan publik. Alasannya menurut Sukriesno Agoes selaku dewan kehormatan IAPI, pada kenyataannya penghasilan dari profesi akuntan publik masih minim namun sangat beresiko, resiko yang dimaksud adalah akuntan harus mampu menjaga independensi. Begitu juga, seperti yang telah diungkap dari hasil penelitian Felton (1994) bahwa gaji jangka panjang lebih dipertimbangkan oleh mahasiswa yang minat berkarir sebagai akuntan publik.

Hasil penelitian ini sejalan dengan hasil penelitian yang dilaksanakan oleh Sari (2013), menunjukkan bahwa penghargaan finansial tidak memiliki pengaruh terhadap minat menjadi akuntan publik. Berbeda dengan penelitian yang dilakukan Yanti (2014), Saputra (2015) dan Rindani (2015).

Tabel 3. Hasil Analisis Regresi

\begin{tabular}{|c|c|c|c|c|c|c|c|}
\hline \multirow[t]{2}{*}{ Model } & \multicolumn{2}{|c|}{$\begin{array}{c}\text { Unstandardized } \\
\text { Coefficients }\end{array}$} & \multirow{2}{*}{$\begin{array}{c}\begin{array}{l}\text { Standardized } \\
\text { Coefficients }\end{array} \\
\text { Beta } \\
\end{array}$} & \multirow[t]{2}{*}{$\mathrm{T}$} & \multirow[t]{2}{*}{ Sig } & \multicolumn{2}{|c|}{$\begin{array}{l}\text { Collinearity } \\
\text { Statistics }\end{array}$} \\
\hline & B & Std.Error & & & & Tolerance & VIF \\
\hline (Constant) & 8.292 & 1.362 & & 6.089 & .000 & & \\
\hline X.1 & -.105 & .079 & -.085 & -1.323 & .187 & .490 & 2.041 \\
\hline X.2 & .086 & .067 & .082 & 1.280 & .202 & .499 & 2.002 \\
\hline X.3 & .239 & .090 & .183 & 2.665 & .008 & .432 & 2.316 \\
\hline X.4 & .207 & .067 & .183 & 3.105 & .002 & .583 & 1.714 \\
\hline X.5 & .165 & .081 & .122 & 2.026 & .044 & .561 & 1.784 \\
\hline X.6 & .394 & .063 & .368 & 6.273 & .000 & .590 & 1.695 \\
\hline
\end{tabular}

\section{Pertimbangan Pasar Kerja dan Minat Berkarir Sebagai Akuntan Publik}

Terbukti bahwa variabel pertimbangan pasar kerja tidak berpengaruh terhadap minat berkarir sebagai akuntan publik (tersaji dalam tabel 3). Hasil penelitian ini membuktikan bahwa setiap kenaikan satu satuan pertimbangan pasar kerja yang diwakilkan dengan tersedianya lapangan pekerjaan untuk profesi akuntan publik yang masih terbuka lebar, jumlah akuntan publik yang tidak sebanding dengan jumlah perusahaan yang harus diaudit, memiliki keamanan kerja yang baik dimasa depan, cenderung terhindar dari resiko pemutusan kerja, dan terdapat kemudahan dalam mengakses lapangan pekerjaan tidak mempengaruhi minat berkarir sebagai akuntan publik. Alasannya seperti yang diungkapkan oleh Ilya Avianti selaku guru besar akuntansi Universitas Padjajaran bahwa pekerjaan akuntan publik hanya ditujukan bagi orang-orang yang "hobi akuntansi". Jadi,meskipun kesempatan kerja menjadi akuntan publik terbuka lebar, jika mahasiswa tidak hobi akuntansi 
cenderung untuk tidak memilih pekerjaan akuntan setelah lulus sebagai pilihan karirnya setelah lulus nanti.

Adapun hasil penelitian Chan (2012) mengungkapkan bahwa mahasiswa yang memiliki minat bekerja sebagai akuntan publik sebagian besar hanya untuk memperoleh pengalaman kerja yang banyak saja, dengan kata lain pekerjaan akuntan publik tidak untuk pekerjaan jangka panjang. Hasil penelitian ini sejalan dengan Wahyuni (2016) dalam penelitiannya berpendapat bahwa pertimbangan pasar kerja tidak mempunyai pengaruh terhadap minat mahasiswa akuntansi untuk berkarir sebagai akuntan publik. Namun demikian, temuan penelitian ini tidak sama dengan penelitian Sari (2013), Yanti (2014) Saputra (2015) dan Rindani (2015).

\section{Pelatihan Profesional dan Minat Berkarir Sebagai Akuntan Publik}

Hasil pengujian menunjukkan bahwa variabel pelatihan profesional berpengaruh signifikan terhadap minat berkarir sebagai akuntan publik (lihat tabel 3). Hasil penelitian ini membuktikan bahwa setiap kenaikan satu satuan pelatihan profesional yang diwakili dengan pelatihan sebelum mulai kerja, pelatihan profesional dan ujian sertifikasi, pelatihan kerja rutin, dan pengalaman kerja yang diukur dari masa kerja, dan dari tingkat pengetahuan serta kemampuan yang dimiliki mempengaruhi minat mahasiswa berkarir sebagai akuntan publik. Hal ini sesuai dengan teori yang dikemukakan oleh Maslow (1954) yaitu kebutuhan akan harga diri. Kebutuhan akan harga diri dibagi dua, salah satunya adalah menghargai diri sendiri yang meliputi kebutuhan akan kemandirian, penguasaan, kekuatan, dan kompetensi percaya diri.

Temuan penelitian ini sama dengan Rindani (2015) yang membuktikan bahwa pelatihan profesional mempunyai pengaruh signifikan terhadap minat mahasiswa akuntansi untuk berkarir menjadi akuntan publik. Hal tersebut tidak sejalan dengan hasil penelitian Sari (2013).

\section{Lingkungan Kerja dan Minat Berkarir Sebagai Akuntan Publik}

Temuan penelitian membuktikan bahwa variabel lingkungan kerja berpengaruh signifikan terhadap minat berkarir sebagai akuntan publik (lihat tabel 3). Artinya setiap kenaikan satu satuan lingkungan kerja yang diwakili dengan pernyataan profesi akuntan publik bersifat pekerjaan yang aktraktif atau banyak tantangan, bersifat pekerjaan yang sering lembur, bersifat pekerjaan yang rutin, memiliki tingkat persaingan yang tinggi, lingkungan kerja yang menyenangkan mempengaruhi minat berkarir sebagai akuntan publik. Penelitian ini sesuai dengan teori dua faktor yang dicetuskan oleh Herzberg (2005) dan teori X \& Y yang dicetuskan oleh McGregor (2000).

Hasil penelitian ini selaras dengan penelitian Wahyuni, dkk (2016) yang didukung penelitian dari Yanti (2014), menunjukkan bahwa lingkungan kerja berpengaruh signifikan terhadap minat berkarir sebagai akuntan publik. Berbeda dengan Sari (2013) yang mengemukakan bahwa lingkungan kerja tidak memiliki pengaruh terhadap minat menjadi akuntan publik.

\section{Pengakuan Profesional dan Minat Berkarir Sebagai Akuntan Publik}

Variabel pengakuan profesional berpengaruh signifikan terhadap minat berkarir sebagai akuntan publik, hal ini terbukti dari hasil uji statistik yang tersaji dalam tabel 3 . Hasil penelitian ini membuktikan bahwa setiap kenaikan satu satuan pengakuan profesional yang diwakili dengan pernyataan profesi akuntan publik menerapkan pengakuan prestasi, profesi akuntan publik memberikan kemungkinan untuk bekerja dengan ahli lain, profesi akuntan publik memberikan kesempatan untuk berkembang, profesi akuntan publik memerlukan keahlian tertentu untuk mencapai sukses mempengaruhi minat berkarir sebagai akuntan 
publik. Penelitian ini sesuai dengan teori yang dikemukakan Maslow (1954) dan Herzberg (2005). Penelitian ini konsisten dengan penelitian Sari (2013), Yanti (2014) serta Wahyuni (2016), mengemukakan pengakuan profesional berpengaruh signifikan terhadap minat berkarir sebagai akuntan publik. Berbeda dengan yang diungkapkan Rindani (2015).

\section{Nilai-Nilai Sosial dan Minat Berkarir Sebagai Akuntan Publik}

Penelitian ini menunjukkan bahwa variabel nilai-nilai sosial berpengaruh signifikan terhadap minat berkarir sebagai akuntan publik (lihat tabel 3). Hasil penelitian ini membuktikan bahwa setiap kenaikan satu satuan nilai-nilai sosial yang diwakili dengan memberikan kesempatan untuk melakukan pelayanan sosial, memberikan kepuasan pribadi, mempunyai waktu luang untuk menjalankan hobi diluar pekerjaan, bersifat pekerjaan yang memiliki gengsi yang tinggi dimata orang lain, dan profesi akuntan publik sebagai cara untuk naik pangkat mempengaruhi minat berkarir sebagai akuntan publik. Penelitian ini selaras dengan teori hierarki kebutuhan yang dikemukakan oleh Maslow (1954) dan teori persepsi.

Hasil penelitian ini sesuai dengan hasil penelitian Wahyuni, dkk. (2016) menyatakan bahwa nilai-nilai sosial berpengaruh signifikan terhadap minat berkarir sebagai akuntan publik. Namun hal berbeda ditunjukkan oleh hasil penelitian Sari (2013), Yanti (2014), dan Rindani (2015) yakni nilai sosial kerja tidak memiliki pengaruh terhadap minat mahasiswa untuk berkarir sebagai akuntan publik.

\section{SIMPULAN}

Atas dasar hasil penelitian mengenai aspek-aspek yang menjadi pertimbangan mahasiswa Universitas Dian Nuswantoro, Universitas Katolik Soegijapranata dan Universitas Stikubank, berkarir sebagai akuntan publik, dapat ditarik kesimpulan sebagai beriktu: (1) penghargaan finansial dan pertimbangan pasar kerja tidak berpengaruh terhadap minat berkarir sebagai akuntan publik, (2) pelatihan professional, lingkungan kerja, pengakuan profesional, dan nilai-nilai sosial berpengaruh signifikan terhadap minat berkarir sebagai akuntan publik.

Adapun saran yang diberikan untuk penelitian selanjutnya antara lain: (1) bagi peneliti selanjutnya disarankan untuk mengembangkan penelitian ini dengan meneliti aspek-aspek lain yang berpengaruh terhadap minat berkarir sebagai akuntan publik yang tidak diteliti oleh peneliti, (2) menambah metoda lain selain kuesioner untuk mengatasi kelemahan-kelemahan yang mungkin terdapat pada metoda kuesioner, misalnya dengan wawancara, (3) menambah lingkup penelitian dengan memakai sampel mahasiswa akuntansi dari perguruan tinggi negeri dan swasta yang lain, misalnya perguruan tinggi sekota semarang, (4) menambahkan variabel, misalnya variabel personalitas, dan gender.

\section{DAFTAR PUSTAKA}

Aldefter, CP. 1972. Existence, Relatedness, and Growth : Human Needs In Organizational Settings. Free Press, New York.

Chan, A. S. 2012. Analisis Faktor-Faktor Yang Mempengaruhi Pemilihan Karir Menjadi Akuntan Publik Oleh Mahasiswa Jurusan Akuntansi. Jurnal Ilmiah Mahasiswa Akuntansi 1 (1): 53-58. 
Felton, S; N. Buhr, dan M. Northey. 1994. Factors Influencing the Business Student's Choice of a Career in Chartered Accountancy, Issues in Accounting Education. Spring.

Hariandja, M.T.E. 2002. Manajemen Sumber Daya Manusia. Grasindo, Jakarta.

Herzberg, F; B. Mausner; dan B. Snyderman. 2005. The Motivation to Work. Wiley, New York.

Maslow, A. 1954. Motivation and Personality. Harper and Bros, New York.

Marwansyah. 2010. Manajemen Sumber Daya Manusia. Edisi Kedua. Cetakan Kesatu. Alfabeta, Bandung.

Mc,Gregor, D. 2000. The Piman Side of enterprise. McGraw-Hill, New York.

Nitisemito. Alex S. 2002. Manajemen Personalia. Edisi Ketiga. Ghalia Indonesia, Jakarta.

Rindani, A. 2015. Faktor-Faktor Yang Mempengaruhi Minat Mahasiswa Akuntansi Untuk Berkarir Sebagai Akuntan Publik (Studi Kasus Pada Pergutuan Tinggi Dengan Program Studi Akuntansi Yang Berakreditasi B Yang Terdapat di Pekanbaru). Jurnal FEKON 2 (2): 1-14.

Sari, M. 2013. Faktor-faktor yang Mempengaruhi Pemilihan Karir Menjadi Akuntan Publik oleh Mahasiswa Departemen Akuntansi Fakultas Ekonomi UMSU Medan. Jurnal Riset Akuntansi dan Bisnis 3 (2): 174- 201.

Wahyuni. 2016. Analisis Faktor-Faktor Yang Mempengaruhi Minat Mahasiswa Akuntansi Untuk Berkarir Menjadi Akuntan Publik. Lembaga Penelitian dan Pemberdayaan Masyarakat (LPPM) UNMAS, Denpasar.

Walgito, B. 2004. Pengantar Psikologi Umum. Andi, Jakarta.

Yanti, N. 2014. Analisis Faktor-faktor yang Mempengaruhi Mahasiswa Akuntansi dalam Pemilihan Karir menjadi Akuntan Publik. Jurnal Online Mahasiswa FEKON 1 (2). 